\title{
National seed legislation: Harmonization with international treaties and conventions
}

\author{
B Thapa Kshetri \\ Seed Quality Control Centre
}

\begin{abstract}
Government of Nepal (GoN) started seed legislation by framing different acts such as Seed Act, 1988 (2045), Seed Regulation 1997(2054) and Seed Policy, 1999 (2056) to regulate seed and seed related issues. Some of these acts have been amended and redrafted according to needs. During this period, GoN, became a contracting party to Convention of Biological Diversity (CBD), 1992 and International Treaty on Plant Genetic Resources for Food and Agriculture (ITPGRFA), 2001. It also signed the Cartagena Protocol, 2000 and received the member of WTO in 2004. In these treaties and convention, Nepal has made commitments in international forum to provide plant variety protection with protecting the rights of farmers and related stakeholders on seed to establish sanitary and phyto-sanitary measures for bio-safety. In this context, it is necessary to reframe the national seed legislations in order to remove its present legal complications and to harmonize it with international treaties and conventions.
\end{abstract}

Key words: seed act, seed legislation, international treaties and conventions

\section{Introduction}

Seed testing works were started from 1961 (B.S. 2018/019) in Nepal (Thapa, 2054) and Central seed Testing Laboratory (CSTL) was established under Agronomy Division of Department of Agriculture in 1962. The main aim was to establish the CSTL and to initiate quality control activities as well as to provide seed testing service to Agriculture Farms for ensuring quality seed supply to farmers. After establishment of Agriculture Botany Division in Khumaltar in 1965, Laboratory came under this division and started quality control activities such as field inspection, seed certification including seed testing services and research on seed science and technology. After agriculture research became autonomous organization and separated from the Department of Agriculture (DoA) in 1992/93, responsibility of seed certification and quality control authorities were still retained to DoA accordingly and Seed Development and Quality Control Service Division (SDQCSD) was established at Harihar Bhawan, Lalitpur (SQCC, 2002). After going through several structural changes, this organization became Seed Quality Control Centre (SQCC) and has been prescribed authority for seed quality control and secretariat of National Seed Board. The laboratory under this Centre is also prescribed as Central Seed Testing Laboratory of Nepal.

Even after 15 years of testing, certification and seed quality control activities in the country, government of Nepal enacted Seed Act, 1988. The preamble of the Act is expedited to maintain the convenience and economic interest of the general public by providing the Seeds of quality-standards in a well planned manner upon producing, processing and testing the seeds of high quality-standards of different crops (Seed Act ,1988). This act was first enacted only in three districts of Kathmandu, Lalitpur, and Bhaktapur enacted from Bhadra 1, 2046. After 9 years of enacting, the Seed Act, 1988, GoN has framed the Seed Regulation 1997 and then again seed act has been enforced in other 30 districts from Magh 1, 2061. However, still other 42 districts of the country are not included in 
the Seed rules and regulation. Usually Seed rules and regulation are framed to implement the seed policy of the country but in our context seed policy (National Seed Policy, 1999) was developed after enacting Seed Act, 1988 and Seed Regulation, 1997 (i.e. B.S. 2056).

\section{Amendment of seed act and international treaties and conventions}

To implement the National seed policy 1999 and to regulate entire quality functions (seed production, distribution and export/import) and effective seed law enforcement in the country, Government of Nepal revised the seed Act 1988 and the first amendment bill was approved from Legislative parliament in 2008 (Thapa et al.; 2009). After the first amendment of Seed Act, 1988, SQCC drafted and finalized a new seed regulation through consultations with stake holders. Recently, GoN has approved the new Seed Regulation 2069 for effective implementation of Seed Act, 1988 in line with international practices. However, still SQCC has important task to draft a comprehensive guidelines in seed quality control to implement seed legislation effectively.

International treaties and conventions such as Convention of Biological Diversity (CBD) 1992, International treaty on Plant Genetic Resources for Food and Agriculture (ITPGRFA) 2001, Trade Related Aspect of Intellectual Property Rights (TRIPS) and other Agreements of World Trade Organization (WTO) and Cartagena protocol, 2000 have direct concern with seed business, farmer right and bio-safety policy on seed. CBD 1992 and ITPGRFA 2001 are two major international legal instruments that deal with access and benefit sharing (ABS), prior informed consent (PIC) in use of biological resources, farmers' right and material transfer agreement on seed. However, TRIPS agreement of WTO has also gained the importance on varietal development and use of biotechnology in the field of agriculture for plant variety protection (PVP). It is also related to ABS and PIC rights of local communities and farmers in use of biological resources in Nepal (Sawtee, 2006). In this scenario, the government of Nepal has obligations to harmonize the existing seed legislation with international treaties and conventions to meet the commitment made in international forum for protecting the rights of the stakeholders on seed. However, existing seed legislation has covered very few issues of international treaties and conventions including right of farmers to participate in making decision on matters related to seed, traditional ownership rights on seed of local crop varieties, requirement of bio-safety report for registration of GMO varieties and ban to register the terminator seed. But still existing seed legislation has some legal complications for its application and there are great challenges for harmonization with other non-covered seed related issues of international treaties and conventions.

\section{International treaties and conventions CBD, 1992}

CBD was adopted on 5 June 1992 at the United Nations Conference on Environment and Development at Rio de Janerio, Brazil. The Convention came into force on 29 December 1993. Currently, 191 countries are contracting parties to CBD. Nepal ratified the Convention on 23 November 1993. As a contracting party to CBD, Nepal has obligation to enact and implement a national Access and Benefit Sharing law. It is therefore, the Ministry of Forest and Soil Conservation, as a focal point, has prepared the draft bill of Access to Genetic resources and Benefit Sharing Act, 2002 which is still under discussion for finalization. The conservation of biological diversity, the sustainable use of its components and the fair and equitable sharing of the benefits arising out of the utilization of genetic resources are the three major objectives of CBD. The ABS and PIC are the two major equity concerns in the commercialization process of biological diversity and Traditional Knowledge (TK) that have been recognized and legitimized in CBD which ensures 
the sovereign rights of the states over their biological resources, so national government, subject to their national laws, is conferred the authority to determine access to genetic resources. According to CBD, access to genetic resources should be on mutually agreed terms and also on PIC of the parties providing the access. The providing and accessing parties are required to establish legal, administrative and policy measures on mutually agreed terms to achieve fair and equitable sharing of technological benefits arising from research and developments, and economic benefits arising from the commercial utilization of genetic resources (Adhikari, 2006).

\section{TRIPS agreement of WTO}

Nepal became the member of WTO since April 2004. It contains several multilateral legally binding agreements to member countries. Among them, TRIPS is the most comprehensive agreement on intellectual property and is a minimum standards agreement, which allows members to provide more extensive protection of intellectual property if they so wish. Members are left free to determine the appropriate method of implementing the provisions of the agreement with their own legal system and practices. The main purpose of granting IPRs is to legally recognize and reward the creator for his/her intellectual creation (Sawtee, 2006). The intellectual property rights include copyright and related rights and industrial property rights (trade mark, geographical indication, patent, industrial design, trade secret, layout design of integrated circuit and plant breeders' right) (WTO, 2006). With legal binding, each member country has to provide plant variety protection either by patent or sui-generis system or combination of both. As a member country, Nepal expressed its commitment to implement the national IPR laws in compliance with the TRIPS Agreement. During its accession to the WTO, Nepal chose to develop a Sui generic system for the protection of plant varieties, that is, granting of plant breeders' rights certificates and not patents to the inventors of new plant varieties. In addition, it has made a commitment to introduce a separate free-standing act to deal with plant variety protection with intended to protect the rights of related stakeholders in accordance with the needs of the country. Ministry of Agriculture Development drafted the Plant Variety Protection and Farmers right Act 2004. The draft mainly focuses to protect the right of the farmers as well as the right of the breeders. According to the drafted bill, rights of the farmers refer rights over their resources and traditional knowledge, assurance of ABS and PIC mechanism and free to save, use, re-use, exchange and sell the seed without any hurdles (Adhikari, 2006).

\section{ITPGRFA 2001}

After more than 15 sessions of the FAO Committee on Genetic Resources and its subsidiary bodies, ITPGRFA was approved during the FAO conference in 2001. The Treaty was introduced to harmonize the International Undertaking on Plant Genetic Resources signed in 1983 with CBD. The Treaty came into force on 29 June 2004 and, until now, 116 countries have ratified it. Nepal ratified ITPGRFA on 2 January 2007 but conformation received at 2009. (Sawtee, 2006). This legally binding treaty covers 64 species of plant genetic resources of food and agriculture for ensuring continuous availability of PGRFA to feed people and assures food security in national and global levels. It does not cover other PGRs such as medicinal and aromatic plants. The provisions of ITPGRFA require members to survey, prepare an inventory, and otherwise conserver PGRFA, and to take legal policy and legal mechanism to promote their sustainable use. Members also agree to provide technical assistance to one another, especially for developing countries. The treaty has recognized that farmers have great contribution in conserving, improving and making available plant genetic resources for sustainable agriculture and food security. It also recognized the rights of 
farmers to have benefit for such contribution through multilateral system. In Article 9 of this treaty, it has accepted that farmers have been playing role of custodians of PGRs from ancient time and provides exclusive rights to farmers for saving, using, exchanging and selling farm saved seed/propagating material. In same Article 9, the treaty also mentions other important farmers' rights such as right to TK; right to participate in sharing benefits; and right to participate in making decisions at the national level. Regarding the implementation of these farmers' rights, the treaty states, "...in accordance with needs and priorities, each contracting party should, as appropriate, and subject to its national legislation, take measures to protect and promote Farmers' Rights". (FAO, 2002).

\section{Cartagena protocol 2000 on bio-safety to CBD}

Nepal has made commitment by signing the Cartagena Protocol on Bio-safety to CBD, 2000 in March 2, 2001, which was effective from 2003. The main objective of the protocol is to pay special attention to the trans-boundary movement of GMOs on the basis of advanced informed agreement. GoN has responsibility to formulate the laws and policies related to the release, use and marketing of GMOs according to the National Bio-safety frame works in Nepal (Shrestha, 2007). In this context, National Seed Policy 2056, National Agriculture Policy 2061 and Agrobio-diversity Policy of Nepal 2063, are some national documents that state some legal frame work on bio-safety for agriculture. The major provisions included in these policies are:

\section{National Seed Policy 2056}

- Policy to conduct study and research on genetically modified organism and transgenic plants developed from genetic engineering and tissue culture technology.

- Import permission shall be given to GMO and transgenic seeds after verification report of authorized government agencies on bio-safety through study and research activities.

- Policy to formulate bio-safety regulation as suitable to our situation. (National Seed Policy, 2056)

\section{National Agricultural Policy 2061}

- Regulate the use of genetically modified organism (National Agriculture Policy 2061).

\section{Agro-biodiversity Policy of Nepal 2063}

- Essential to take permission from authority to conduct study and research and import of infectious and genetically/living modified organism.

- As necessary, policy to regulate or ban to the GMO/LMO seed and its products that has risk of negative impact on bio-diversity, environment and human health (Agrobio-diversity Policy of Nepal 2063)

\section{Existing seed legislation and its key features}

\section{Seed policy 2056}

National Seed Policy 2056 (1999) covers following seven issues related to seed business and Biotechnology: 


\section{Variety development and maintenance}

- Involvement of private sectors for developing new varieties and maintaining the breeder seed of those varieties with certain terms and conditions.

- Approval, release and registration of new varieties before distribution to farmers' level through National Seed Board (NSB).

- De-notification of variety which is technically unsuitable for cultivation

- Provision to grant rights on local variety for bio-diversity conservation.

- To encourage for custom seed production in between government/private sector with international seed company.

\section{Seed multiplication}

- Seed production system - Nucleus/pre-basic seed, breeder seed, Foundation seed, certified seed and improved seed.

- Encourage to produce and export the high value seed.

- Breeders are responsible for production and maintenance of breeder seed.

- Preparation of balance sheet for assurance of source seed.

- Seed zoning, arrangement of registered seed producers and encourage to contract seed production.

- NSB (National Seed Board) is preparing seed balance sheet for assured program and plan for supplying Breeder seed and Foundation/source seed.

\section{Quality control}

- In addition to seed certification and truthful labeling, planning to execute Quality Declared Seed System for quality control in Nepal.

- Licensing system to provide seed quality control services in the field of seed testing, crop inspection and seed sampling as prescribed.

- Monitoring of licensing system by Seed Quality Control Centre.

\section{Increase involvement of private sector in seed business}

- As demanded, government seed processing plant and seed storage facilities shall be make available to private sector with service charge.

- Reimbursement of certain percentage of interest incurred in seed pledging system to maintain the price of seed at affordable level.

- Subsidy on custom and local tax in seed business.

- Training and skill development opportunity to entrepreneurs.

- With recommendation of NSB, seed companies, registered as agriculture industry or categorized in primary sector, shall get the facilities as prescribed by Industrial Development Act, 2038. 
- With recommendation of NSB, financial support to private sector for advertisement of quality seed through mass media.

\section{Seed supply arrangement}

- Maintain the up to date record of seed demand, supply and production of public and private sectors and make provision of information system to farmers' level through NSB effectively.

- For assurance of seed supply system, maintain buffer stock of seed at national level.

- Subsidy to construct and run cold storage for promoting seed business.

- Emphasis to use modern bio-technology for production of disease free seeds and seedlings in public and private sectors.

- In addition to cereals seed for food security, emphasis to produce and distribute pasture, flower and other seeds as well.

- Organizing and managing the programs such as farmers' group formation, revolving fund, technical service and transportation subsidy on seed for strengthening the seed program in remote areas of the country.

\section{Institutional strengthening-}

- Arrangement of manpower and resources for strengthening Secretariat of NSB/ SQCC.

- Arrangement of manpower in SQCC for seed quality control.

- In addition to government laboratories for seed testing, authority to establish and run laboratories in private sectors.

- Institutional arrangement to manage seed pledging system.

- Commercialization of semi-government organization involved in seed business gradually.

- Institutional strengthening of government organization involved in seed research and production.

\section{Bio- technology}

- Policy to conduct study and research on genetically modified organism and transgenic plants developed from genetic engineering and tissue culture technology.

- Import permission to GMO and transgenic seeds only after verification report of authorized government agencies on bio-safety through study and research activities.

- Policy to formulate bio-safety regulation as suitable to our situation.

- Arrangement of manpower and physical infrastructure to develop modern technology in Nepal (National Seed Policy, 2056).

\section{Seed legislation (Seed act, 1988 and seed regulation 2013/2069)}

The main features of Seed Act, 1988 and Seed Regulation 2013(2069) are:

- Constitute/functions duties and power of National Seed Board.

- Provision of approval, release and registration of variety and ownership rights to breeders. 
- Power to constitute sub committees under National Seed Board.

- Establishment/functions, duties and responsibilities of Seed Quality Control Centre.

- Seed Quality Control System and validity period of seed testing.

- Establishment/functions, duties and responsibilities of Central Seed Testing Laboratory and other seed testing laboratories establish in public and private sectors.

- Procedures for licensing, renewal and withdraw the license of private seed testing laboratories.

- Power to notify the kind and varieties and prescribe the seed quality attributes and its minimum standards.

- Compulsory provision of truthful labeling of container of notified kind varieties (i.e. voluntary seed certification) and necessary information on it.

- Registration provision of seed traders and ban to sell un-notified kind varieties.

- Permission from NSB for import and export of notified kind varieties from Nepal.

- Provision of crop inspector, seed sampler, and seed analyst and their minimum qualification and examination procedures.

- Procedures for renew and revoke the license of seed traders, crop inspector, seed analyst and seed sampler.

- Functions, duties and responsibilities of crop inspector, seed sampler, and seed analyst

- Compensation system to farmers in case of low quality and wrong information about seed.

- Provision of seed service charge.

- Recognition provision to national and international organization involved in seed testing, certification and DUS test

- Ownership rights on traditionally used local varieties of crop.

- Provision to institute the cases and punishment.

- Power to hear and appeal the cases and frame out seed rules for seed law enforcement.

\section{Present issues for implementation of seed legislation}

More than 60 years long history of seed program in Nepal, now GoN is in position to implement the seed legislation in country. During this period, several workshop, seminar, meeting, and discussion have been completed in joint collaboration with concern stakeholders to draft, revise and refine the existing seed legislations. However, present seed legislation still has some lacking that may cause problems during implementation. Including these, some other legal complications may come during implementing period. Hence, it is necessary to correct these legal complications during the time of revising the seed legislation again. Some legal complications and its necessary corrections are given in tables (Table 1- 5). 
Table 1. Legal complications and their necessary correction as proposed

$\begin{array}{ccc}\text { P.N } & \begin{array}{c}\text { Present lacking, legal } \\ \text { complications }\end{array} & \text { Necessary corrections/required of tasks }\end{array}$

Seed Act, 1988 is enforced only in 33 districts

Licensing provision to seed law enforcement personnel i.e. seed sampler

Unnecessary power to crop inspector to seize the seed?

Technical officers of government seed testing laboratories are assigned as seed sampler?

Minimum seed quality standards are not prescribed after amendment of seed act.

No necessary guidelines to implement the seed legislation.

Private laboratories need license for seed testing, not for government laboratories, why? (is it due to well equipped or technically sound manpower? or laboratories are running at accreditation standard?)

Till date, no agency is recognized for bio-safety report for registration of GM variety.
Necessary to enforce in all 75 districts by notification.

Only licensing provision should be to seed analyst and crop inspector as they are only service provider (needs to revise Seed Act, 1988).

Need to handover this duty to Seed Law Enforcement Officer (seed sampler) (needs to revise Seed Act, 1988).

Authorize them for seed testing and field inspection for the purpose of seed testing and certification only (needs to revise Seed Regulation, 2069).

By notification, minimum seed quality attributes and minimum seed standards shall be prescribed immediately for implementing seed legislation.

Needs to frame out comprehensive guidelines for seed quality control on

- Procedures for licensing exam

- Compensation guideline

- Seed certification and seed sampling (size, color of TL)

- Licensing standard of Private Seed Testing Laboratory.

- Registration procedures for seed traders and variety

- Procedures to damage the seized seeds.

- Monitoring and license withdrawal procedures of seed analyst and crop inspector.

Needs to strengthen government laboratories to run it at accreditation standard to answer the frequently raised question from private sectors.

GoN, by notification, shall recognized national or international agencies for bio-safety report (needs to revise Seed Act, 1988). 


\section{S.N Present lacking, legal Necessary corrections/required of tasks complications}

Two seasons trial report for variety registration procedure for seed import - not practical in our situation

Notified kind varieties shall be sold 0 only within the recommended area.
Simplify the variety registration procedures through making responsible to seed importer.

Legal commitment to provide compensation to farmers if they fail to get harvest due to quality, wrong information and varietal adaptability problem of seed (needs to revise Seed Regulation, 2069).

Notified kind varieties can be sold throughout the country but for only recommended areas (needs to revise Seed Act, 1988).

Table 2. International treaty/convention and seed concerns CBD, 1992

\begin{tabular}{|c|c|c|c|}
\hline $\begin{array}{l}\text { Obligations/Key } \\
\text { points }\end{array}$ & Seed related issues & $\begin{array}{c}\text { Existing rules and } \\
\text { practices }\end{array}$ & Necessary amendments \\
\hline $\begin{array}{l}\text { Legal provision for } \\
\text { fair and equitable } \\
\text { sharing of benefit } \\
\text { arising from the } \\
\text { utilization of } \\
\text { genetic resources }\end{array}$ & $\begin{array}{l}\text { Farmers and local } \\
\text { communities may have } \\
\text { opportunity to share the } \\
\text { benefit arising from the } \\
\text { use of their genetic } \\
\text { resources during varietal } \\
\text { development through } \\
\text { hybridization and modern } \\
\text { bio-technology. } \\
\text { Hence, it is necessary to } \\
\text { disclose the parents of the } \\
\text { variety. }\end{array}$ & $\begin{array}{l}\text { Disclosure } \\
\text { requirement may } \\
\text { not applicable in } \\
\text { case of farmers' } \\
\text { variety while seed } \\
\text { company may or } \\
\text { may not disclose } \\
\text { the parental lines of } \\
\text { hybrid varieties } \\
\text { (Seed Regulation } \\
\text { 2069) }\end{array}$ & $\begin{array}{l}\text { Provision to issue variety } \\
\text { registration certificates } \\
\text { even for local and } \\
\text { indigenous and farmers' } \\
\text { developed variety to } \\
\text { person/organization and } \\
\text { community. } \\
\text { Disclosure requirement } \\
\text { shall be compulsory } \\
\text { during approval, release, } \\
\text { and registration of the } \\
\text { varieties to assure ABS } \\
\text { and PIC mechanism. }\end{array}$ \\
\hline
\end{tabular}

Table 3. TRIPS agreement of WTO

\begin{tabular}{|c|c|c|c|}
\hline $\begin{array}{l}\text { Obligations/Key } \\
\text { points }\end{array}$ & Seed related issues & $\begin{array}{l}\text { Existing rules } \\
\text { and practices }\end{array}$ & $\begin{array}{l}\text { Necessary } \\
\text { amendments }\end{array}$ \\
\hline $\begin{array}{l}\text { "To introduce a } \\
\text { separate free- } \\
\text { standing act to deal } \\
\text { with plant variety } \\
\text { protection with } \\
\text { intended to protect } \\
\text { the rights of related } \\
\text { stakeholders in } \\
\text { accordance with the } \\
\text { needs of the country" }\end{array}$ & $\begin{array}{l}\text { GON, MOAD drafted PVP } \\
\text { \& FR bill } 2004 \text { for dealing } \\
\text { rights of farmers as well as } \\
\text { the rights of the breeders } \\
\text { Seed Act, } 1988 \text { shall address } \\
\text { only concerns of seed } \\
\text { business and quality control } \\
\text { so it shall exclude the } \\
\text { provision of ownership } \\
\text { rights to breeders. }\end{array}$ & $\begin{array}{l}\text { Provision to } \\
\text { granting } \\
\text { ownership rights } \\
\text { to breeders for } \\
\text { new variety but } \\
\text { not practiced yet. }\end{array}$ & $\begin{array}{l}\text { Excluding the } \\
\text { provision of } \\
\text { ownership rights to } \\
\text { breeders as well as } \\
\text { farmers from the Seed } \\
\text { Act, } 1988 \text {. }\end{array}$ \\
\hline
\end{tabular}




\begin{tabular}{|c|c|c|c|}
\hline $\begin{array}{l}\text { Obligations/Key } \\
\text { points }\end{array}$ & Seed related issues & $\begin{array}{l}\text { Existing rules } \\
\text { and practices }\end{array}$ & $\begin{array}{l}\text { Necessary } \\
\text { amendments }\end{array}$ \\
\hline & $\begin{array}{l}\text { Rights of related stakeholder } \\
\text { refer right of farmers as well } \\
\text { as right of breeders. } \\
\text { Breeder's definition of Seed } \\
\text { Act, } 1988 \text { allows farmers to } \\
\text { enjoy rights of breeder. } \\
\text { Farmer, as a breeder, may } \\
\text { not have academic degree } \\
\text { from the university. }\end{array}$ & $\begin{array}{l}\text { Existing rules } \\
\text { prescribe the } \\
\text { qualification of } \\
\text { breeder that } \\
\text { restricts the } \\
\text { farmers to enjoy } \\
\text { the rights of } \\
\text { breeder in our } \\
\text { context (Notice } \\
\text { published by NSB } \\
\text { in Gorkhapatra on } \\
\text { 2062.8.4). }\end{array}$ & $\begin{array}{l}\text { Revise the notice } \\
\text { according to the } \\
\text { definition Seed Act, } \\
1988 \text { to allow farmers } \\
\text { to enjoy the rights of } \\
\text { breeders. }\end{array}$ \\
\hline
\end{tabular}

Table 4. ITPGRFA 2001

\begin{tabular}{|c|c|c|c|}
\hline $\begin{array}{l}\text { Obligations/Key } \\
\text { points }\end{array}$ & Seed related issues & $\begin{array}{l}\text { Existing rules } \\
\text { and practices }\end{array}$ & Necessary amendments \\
\hline $\begin{array}{l}\text { Article } 9 \text { states } \\
\text { exclusive rights to } \\
\text { farmers on: Rights } \\
\text { to save, use, } \\
\text { exchange and sell } \\
\text { farm saved } \\
\text { seed/propagating } \\
\text { material. } \\
\text { Right to Traditional } \\
\text { Knowledge; } \\
\text { Right to participate } \\
\text { in sharing benefits; } \\
\text { Right to participate } \\
\text { in making } \\
\text { decisions at the } \\
\text { national level }\end{array}$ & $\begin{array}{l}\text { Farmers are } \\
\text { conserving, producing, } \\
\text { developing, protecting, } \\
\text { selling, and using seeds } \\
\text { from ancient age. They } \\
\text { are custodian of seed as } \\
\text { genetic resources. } \\
\text { Right to register } \\
\text { local/indigenous } \\
\text { /farmers' varieties in } \\
\text { free of cost for seed } \\
\text { business } \\
\text { Differentiate the } \\
\text { farmers and seed } \\
\text { traders/company/seed } \\
\text { business man for } \\
\text { ensuring farmers' rights } \\
\text { to save, use, exchange, } \\
\text { and sell any kind of } \\
\text { seed and propagating } \\
\text { material without any } \\
\text { hurdle. }\end{array}$ & $\begin{array}{l}\text { No definition of } \\
\text { seed business in } \\
\text { Seed Act, } 1988 \\
\text { hence, farmers } \\
\text { also need to take } \\
\text { permission for } \\
\text { selling seeds of } \\
\text { notified kind } \\
\text { varieties. } \\
\text { Field testing } \\
\text { charge for } \\
\text { registration of } \\
\text { imported seed. } \\
\text { Ban to sell un- } \\
\text { notified kind } \\
\text { varieties, hence } \\
\text { legally farmers } \\
\text { can not sell their } \\
\text { farm saved un- } \\
\text { notified kind } \\
\text { varieties. }\end{array}$ & $\begin{array}{l}\text { Include the definition of seed } \\
\text { business in Seed Act, } 1988 \text { to } \\
\text { differentiate farmers' and } \\
\text { seed traders/company/ } \\
\text { business man for } \\
\text { implementing compulsory } \\
\text { truthful labeling to regulate } \\
\text { the seed market. } \\
\text { Re-draft the Seed Act with } \\
\text { Including provisions for } \\
\text { assuring the right to farmers } \\
\text { to sell their any kind of farm } \\
\text { saved seed and propagating } \\
\text { materials (notified/un- } \\
\text { notified) without permission } \\
\text { and without labeling and } \\
\text { branding. } \\
\text { No compensation system to } \\
\text { non-labeled and non-branded } \\
\text { seed. } \\
\text { Provide facilities to farmers } \\
\text { to register their } \\
\text { local/indigenous /farmers' } \\
\text { varieties in free of cost for } \\
\text { seed business. }\end{array}$ \\
\hline
\end{tabular}


Agronomy Journal of Nepal (Agron JN) Vol. 3. 2013

Table.5 Cartagena protocol 2000 on Bio-safety to CBD

\begin{tabular}{|c|c|c|c|}
\hline Obligations/Key points & Seed related issues & $\begin{array}{l}\text { Existing rules and } \\
\text { practices }\end{array}$ & $\begin{array}{l}\text { Necessary } \\
\text { amendments }\end{array}$ \\
\hline $\begin{array}{l}\text { Tran boundary } \\
\text { movement of GMOs on } \\
\text { the basis of advanced } \\
\text { informed agreement } \\
\text { Need to formulate the } \\
\text { laws and policies related } \\
\text { to the release, use and } \\
\text { marketing of GMOs }\end{array}$ & $\begin{array}{l}\text { Policy to regulate or } \\
\text { ban to GMO seed. }\end{array}$ & $\begin{array}{l}\text { Mandatory to submit } \\
\text { bio-safety report for } \\
\text { registration of GMO } \\
\text { Seeds. }\end{array}$ & $\begin{array}{l}\text { Including provision in } \\
\text { Seed Act, } 1988 \text { to } \\
\text { recognize the national } \\
\text { or international } \\
\text { organization for bio- } \\
\text { safety report. }\end{array}$ \\
\hline
\end{tabular}

\section{Additional works needed to regulate the use of GMO Seeds are:}

- To frame bio-safety Act, Rules and Guidelines in order to regulate the use, development, import, movement, storage, and release of GMOs.

- National Bio-safety Committee.

- Assess potential risks of GMO to human health, environment and biodiversity

- Mandatory labeling of GMOs

- Establish emergency response procedures

- Nepal bio-safety clearing house (Pant, 2009).

\section{Ways forward}

GoN has to organize the core group discussion of stakeholders and necessary to revise, refine and finalize the seed rules and regulation with following amendments to remove its present complications and to harmonize it with international treaties and conventions. These amendments will help establish the legal measure to implement the plant variety protection in the country with protecting the rights of the farmers as committed in WTO accession as well as CBD 1992 and ITPGRFA, 2001.

- Necessary to prescribe the minimum seed quality standards immediately for truthful labeling.

- Licensing provision should be authorized to crop inspector and seed analyst as they are only service provider.

- Power of crop inspector to seize the seed should be transferred to Seed Law Enforcement Officer (i.e. Seed Sampler).

- Assign the authority of seed testing and field inspection to technical officers of government seed testing laboratories and research institutes of seed testing service and certification.

- Preparation of comprehensive guidelines for seed quality control and regulate seed market.

- Strengthen seed testing laboratory and standardize in accordance with international seed accreditation standard laboratory.

- Provide recognition to authorized national and international government agencies to produce bio-safety report for registration of GM varieties. 
- Simplify the variety registration procedures with provisions to make whole sole responsible to seed importers on seed quality, information, and adaptability of the imported variety.

- Keep mandatory provisions for disclosure requirement of parental lines during approval, release and registration of the variety to assure fair and equitable sharing of benefits arising from the utilization of genetic resources.

- Exclude the provision of granting ownership rights to breeders as well as farmers from the Seed Act, 1988. However, provision to provide variety registration certificate to local, indigenous and farmers' variety alike to release of varieties should be incorporated.

- Reframe the rules so that farmers can enjoy the rights of breeder.

- Defining the term "seed selling business" to differentiate farmers and seed traders/company to implement compulsory truthful labeling on for seed business.

- Only compensation provision should be to the truthful label/certified seeds.

- Including the provision to allow farmers to save, use, re-use, exchange, and sell any kind of seed or propagating materials without permission, labeling and branding.

\section{References}

Adhikari. K. 2006. Legal Mechanisms to Protect Farmers' Rights in Nepal. South Asia Watch on Trade, Economics \& Environment (SAWTEE). Kathmandu, Nepal.

FAO. 2002. International Treaty on Plant Genetic Resources for Food and Agriculture. Adopted by the Thirty-First Session of the Conference of the Food and Agriculture Organization of the United Nations on 3 November 2001. Rome: The Food and Agriculture Organization of the United Nations.

National Agricultural Policy. 2061.

National Bio-diversity Policy. 2063.

National Seed Policy. 2056.

Panta, KP. 2009. Nepalma Krishi Jaibik Bibidhata Neeti, Jaibikprabidhi Neeti Ra Jaibik Suraksha (Nepali version). ABS training 17-19 June, 2009 LI-BIRD and SAWTEE, Pokhara, Nepal.

SAWTEE. 2006. Access, Benefit Sharing and Prior Informed Consent under CBD, ITPGRFA and TRIPS: Legal Mechanisms to Protect Farmers' Rights in South Asia. Kathmandu: South Asia Watch on Trade, Economics \& Environment (SAWTEE).

Seed Act. 1988. Government of Nepal.

Shrestha, TR. 2007. National Bio-safety framework in Nepal. Regional Biosecurity Workshop, Bangkok, Thailand, December 7-9,2007

SQCC. 2003. Seed Quality Control Center, His Majesty's Government, Ministry of Agriculture and Cooperatives, Hariharbhawan, Lalitpur, Nepal.

Thapa, B. 2054. Agriculture Information, Division, DoA, Booklet series; 1.

Thapa, M., LP Acharya and B Thapa. 2008. Existing Seed Policies, Seed Regulatory Frameworks and Quality Assurance System in Nepal: Ways Forward. Paper presented at the Fourth National Seed Seminar. 19-20 June. Organized by National Seed Board at Lalitpur, Nepal. 